\title{
Gaya kepemimpinan situasional kepala sekolah dan budaya organisasi sebagai determinan kinerja guru
}

\author{
(The role of principal leadership situational and organizational culture as \\ determinant teacher performance)
}

\author{
Julina Aisyafarda', Alit Sarino ${ }^{2 *}$ \\ ${ }^{1,2}$ Program Studi Pendidikan Manajemen Perkantoran, \\ Fakultas Pendidikan Ekonomi dan Bisnis, Universitas Pendidikan Indonesia \\ Jl. Dr. Setiabudhi, No. 229 Bandung, Jawa Barat Indonesia \\ Email: alitsarino@upi.edu
}

\begin{abstract}
ABSTRAK
Penelitian ini bertujuan untuk menganalisis pengaruh gaya kepemimpinan situasional kepala sekolah dan budaya organisasi terhadap kinerja guru. Metode penelitian menggunakan survey explanatory. Teknik pengumpulan data menggunakan angket model rating scale. Responden adalah 38 guru di salah satu Sekolah Menengah Kejuruan swasta di Kota Cimahi. Teknik analisis data menggunakan analisis regresi. Hasil penelitian menunjukan bahwa gaya kepemimpinan situasional kepala sekolah dan budaya organisasi memiliki pengaruh yang positif dan signifikan terhadap kinerja guru secara simultan. Oleh karena itu, Oleh karena itu, kinerja guru dapat ditingkatkan melalui peningkatan gaya kepemimpinan situasional kepala sekolah dan budaya organisasi.
\end{abstract}

Kata Kunci: Gaya Kepemimpinan Situasional Kepala Sekolah; Budaya Organisasi; Kinerja Guru

\begin{abstract}
This study aimed to determine the influence of The Role of Principal Leadership Situasional and Organizational Culture on Teacher Performance. The research method used explanatory survey. Data collection technique used questionnaire rating scale models. Respondents are 38 teachers of Vocational High School in Cimahi. Data were analyzed using regression. The results of the study revealed that The Role of Principal Leadership Situasional and Organizational Culture a positive and significant influence on Teacher Performance simultaneously. Therefore, the Teacher Performance can be improved through improving The Role of Principal Leadership Situasional and Organizational Culture.
\end{abstract}

Keywords: The Role of Principal Leadership Situasional; Organizational Culture; Teacher Performance

Received: Februari 2019, Revision: Mei 2019, Published: Juli 2019

*Corresponding author

Copyright (C) 2019, EISSN 2656- 4734 


\section{PENDAHULUAN}

Guru merupakan komponen penting dalam dunia pendidikan, maka diperlukan perhatian yang lebih agar dapat menciptakan guru yang berkualitas sehingga hal tersebut dapat menunjang kinerja guru. Fachrurozi (2014) Guru juga memegang peran penting dalam dunia pendidikan khususnya dalam bidang formal disekolah, guru sangat menentukan keberhasilan peserta didik terutama dalam hal proses belajar mengajar yang biasa dilaksanakan di sekolah. Maka wajarlah apabila rendahnya kualitas pendidikan disangkakan pada guru, mengingat pentingnya peran guru sebagai ujung tombak pendidikan.

Kinerja guru adalah perilaku sesorang yang membuahkan hasil kerja tertentu setelah memenuhi sejumlah persyaratan". (Hamzah B. Uno dan Lamatenggo, 2012.) Kinerja guru merupakan salah satu bagian dari manajemen pendidikan dalam proses pembelajaran yang erat kaitannya dengan konteks sosial dalam meraih tujuan pendidikan dengan efektif dan efisien (Triwahyuni, Abdullah, \& Sunaryo, 2014).

Hasil studi pendahuluan menunjukkan bahwa kinerja guru masih belum optimal. Hal ini ditunjukkan dengan proses kegiatan belajar yang hanya memenuhi target kurikulum. Sejalan dengan data yang diperoleh mengenai proses pembelajaran di Indonesia menyatakan bahwa guru yang membuat Rancangan Program Pembelajaran (RPP) hanya 52\%, guru yang menguasai materi pembelajaran $60 \%$, guru yang menggunakan metode pembelajaran yang tepat 55\%, guru yang melakukan praktek di kelas sekitar 15\%, guru yang melakukan alat evaluasi dengan indikator yang tepat $50 \%$ dan guru yang berpartisipasi dalam pengembangan kurikulum hanya $40 \%$ saja (Triwahyuni, Abdullah, \& Sunaryo, 2014). Data lain yang menunjukkan bahwa kinerja guru belum optimal adalah Penilaian Kinerja Guru. Dari data yang diperoleh mengenai Penilaian Kinerja Guru menunjukkan guru yang mempunyai nilai dengan kategori Amat Baik hanya 2\%, kategori Baik 46\% dan kategori Cukup Baik 52\%.

Pertanyaan yang segera muncul adalah mengapa kinerja guru belum optimal? Merujuk pada perspektif teori perilaku (Luthan, 2002), banyak faktor yang dapat mempengaruhi kinerja guru. Faktor gaya kepemimpinan situasional kepala sekolah dan budaya organisasi merupakan dua faktor yang diduga kuat mempengaruhi kinerja guru, sehingga dijadikan kajian dalam penelitian ini.

Berdasarkan hal tersebut rumusan masalah dari penelitian ini adalah "adakah pengaruh gaya kepemimpinan situasional kepala sekolah dan budaya organisasi terhadap kinerja?". Dengan demikian tujuan dari penelitian ini adalah untuk menganalisis pengaruh gaya kepemimpinan situasional kepala sekolah dan budaya organisasi terhadap kinerja

\section{TINJAUAN PUSTAKA}

\section{Gaya Kepemimpinan Situasional Kepala Sekolah}

Gaya kepemimpinan situasional kepala sekolah merupakan salah satu faktor yang mempengaruhi kinerja guru. Gaya kepemimpinan adalah pola menyeluruh dari tindakan seorang pemimpin, baik yang tampak maupun tidak tampak oleh bawahannya. Gaya kepemimpinan situasional adalah gaya kepemimpinan yang berfokus pada kesesuaian tingkat kematangan atau perkembangan yang relevan dari para pengikut. Kematangan dalam kepemimpinan situasional dirumuskan sebagai kemampuan dan kemauan dari orang-orang untuk bertanggung jawab dalam mengarahkan perilakunya yang berkaitan dengan tugas tertentu. (Thoha, 2012, hlm. 322-324). 
Gaya kepemimpinan seorang pemimpin diduga akan sangat mempengaruhi kondisi kerja, dimana akan berhubungan dengan bagaimana guru menerima suatu gaya kepemimpinan, senang atau tidak, suka atau tidak. Di satu sisi gaya kepemimpinan tertentu diduga dapat menyebabkan peningkatan kinerja disisi lain dapat menyebabkan penurunan kinerja. Dalam usaha untuk mempertahankan dan meningkatkan kinerja guru, sangat diperlukan seorang pemimpin yang menggunakan gaya kepemimpinan situasional, yaitu pemimpin yang selain mempunyai kemampuan pribadi, juga mampu membaca keadaan bawahannya serta lingkungan kerjanya. Dalam hal ini kematangan bawahan berkaitan langsung dengan gaya kepemimpinan yang tepat untuk diterapkan, agar pemimpin memperoleh ketaatan atau pengaruh yang memadai. Untuk itu pemimpin harus mampu menciptakan suasana kerja yang mendukung para bawahan untuk selalu berprestasi. (Suyadnya, Natajaya, \& Arya Sunu, 2013)

Untuk peningkatan gaya kepemimpinan situasional kepala sekolah yang dapat kita lakukan adalah mengidentifikasi beberapa indikatornya dalam tahap-tahap tertentu. Indikator gaya kepemimpinan situasional kepala sekolah antara lain menurut Hersey dan Blanchard dalam (Thoha, 2010, hlm. 65):

1) Instruksi (memberitahukan)

Ini ditujukkan oleh perilaku pemimpin yang tinggi pengarahan dan rendah dukungan, gaya ini dicirikan dengan komunikasi satu arah. Pemimpin memberikan batasan peranan pengikutnya dan memberitahu mereka tentang apa, bagaiman, bilamana dan dimana melaksanakan berbagai tugas. Inisiatif pemecahan masalah dan pembuatan keputusan semata-mata dilakukan oleh pemimpin. Pemecahan masalah dan keputusan diumumkan dan pelaksanaannya diawasi secara ketat oleh pemimpin.

2) Konsultasi (menjajakan)

Ini ditunjukkan oleh perilaku pemimpin yang tinggi pengarahan dan tinggi dukungan, dalam menggunakan gaya ini pempimpin masih banyak memberikan pengarahan dan masih membuat hampir sama dengan keputusan, tetapi hal ini diikuti dengan meningkatkan komunikasi dua arah dan perilaku mendukung, dengan berusaha mendengar perasaan pengikut tentang keputusan yang dibuat, serta ide-ide dan saran-saran mereka. Meskipun dukungan ditingkatkan, pengendalian (control) atas pengambilan keputusan tetap pada pemimpin.

3) Parstisipasi (mengikutsertakan)

Ini ditunjukkan oleh perilaku pemimpin yang tinggi dukungan dan rendah pengarahan. Posisi kontrol atas pemecahan masalah dan pembuatan keputusan dipegang secara bergantian. Dengan penggunaan gaya 3 ini, pemimpin dan pengikut saling tukar-menukar ide dalam pemecahan masalah dan pembuat keputusan. Komunikasi dua arah ditingkatkan, dan peranan pemimpin adalah secara aktif mendengar. Tanggung jawab pemecahan masalah dan pembuatan keputusan sebagian besar berada pada pihak pengikut. Hal ini sudah sewajarnya karena pengikut memiliki kemampuan untuk melaksanakan tugas.

4) Delegasi (mendelegasikan)

Ini ditunjukkan oleh perilaku pemimpin yang rendah dukungan dan rendah pengarahan. Pemimpin mendiskusikan masalah bersama-sama dengan bawahan sehingga tercapai kesepakatan mengenai definisi masalah yang kemudian proses pembuatan keputusan didelegasikan secara keseluruhan kepada bawahan. Sekarang bawahanlah yang memiliki kontrol untuk memutuskan tentang 
bagaimana cara pelaksanaan tugas. Pemimpin memberikan kesempatan yang luas bagi bawahan untuk melaksanakan pertunjukkan mereka sendiri karena mereka memiliki kemampuan dan keyakinan untuk memikul tanggungjawab dalam pengarahan perilaku mereka sendiri.

\section{Budaya Organisasi}

Budaya organisasi merupakan faktor kunci yang memainkan peran penting dalam kegiatan sehari-hari (Sun, 2008). Budaya organisasi merupakan faktor intrinsik dari perilaku organisasi (Janicijevic, 2013). Budaya organisasi didefinisikan dalam karakteristik khas organisasi (Robbins, 2006), (Luthan, 2002), nilai-nilai, keyakinan, adat istiadat (Sun, 2008), (Purnama, 2013), norma-norma (Gibson, Luthan, \& Stear, Organisasi. Perilaku Struktur, Proses., 1996), asumsi dan etika yang memberikan simbol kepada setiap anggota di dalam organisasi (Janicijevic, 2013).

Budaya organisasi dapat diukur dengan enam indikator, yaitu observed behavior regularities, norms, dominant values, philosophy, rules dan organization climate. Observed behavior regularities merupakan budaya organisasi di sekolah yang ditandai dengan adanya keberaturan cara bertndak dari seluruh anggota sekolah yang dapat diamati. Norms yaitu norma-norma yang berisi tentang standar perilaku dari anggota sekolah baik bagi siswa maupun guru. Dominant values yaitu adanya nilai-nilai inti yang dianut bersama oleh seluruh anggota organisasi, misalnya tentang kualitas lulusan siswa yang bagus. Philosophy yaitu adanya kebijakan-kebijakan yang berkenaan dengan kayakinan organisasi sekolah dalam memperlakukan setiap warga sekolah. Rules yaitu adanya pedoman yang ketat, dikaitkan dengan kemajuan organisasi sekolah. Organization climate yaitu perasaan keseluruhan yang tergambarkan dan disampaikan melalui kondisi tata ruang, cara beinteraksi para anggota sekolah, dan cara anggota memperlakukan dirinya dan warga sekolah atau orang lain (Luthan, 2002).

\section{Kinerja Guru}

Kinerja merupakan kegiatan yang dilakukan untuk melaksanakan tugas dan tanggung jawab sesuai dengan harapan dan tujuan yang telah ditetapkan. (Supardi, 2014) meliputi pelaksanaan tugas pembelajaran sebaik-baiknya dalam perencanaan program pengajaran, pelaksanaan kegiatan pembelajaran dan evaluasi hasil pembelajaran (Suyanto \& Djihad, 2012). Oleh karena itu, kinerja dapat diartikan sebagai hasil kerja yang dapat dicapai oleh seseorang atau sekelompok orang dalam suatu organisasi dalam rangka upaya mencapai tujuan secara legal.

Kinerja guru dipengaruhi oleh banyak faktor. Dalam penelitian ini hanya dikaji dua faktor, yaitu gaya kepemimpinan situasional kepala sekolah dan budaya organisasi. Hal ini disandarkan pada argumen bahwa gaya kepemimpinan situasional kepala sekolah dan budaya organisasi berpengaruh terhadap kinerja guru (Flemming, 2009).

Indikator kinerja meliputi 1) Kualitas kerja 2) Kecepatan / ketepatan kerja 3) Inisiatif Dalam kerja 4) Kemampuan kerja 5) Komunikasi (Hamzah \& Lamatenggo, 2012)

Berdasarkan tinjauan pustaka sebagaimana dipaparkan di atas, dapat digambarkan theoretical framework seperti berikut: 


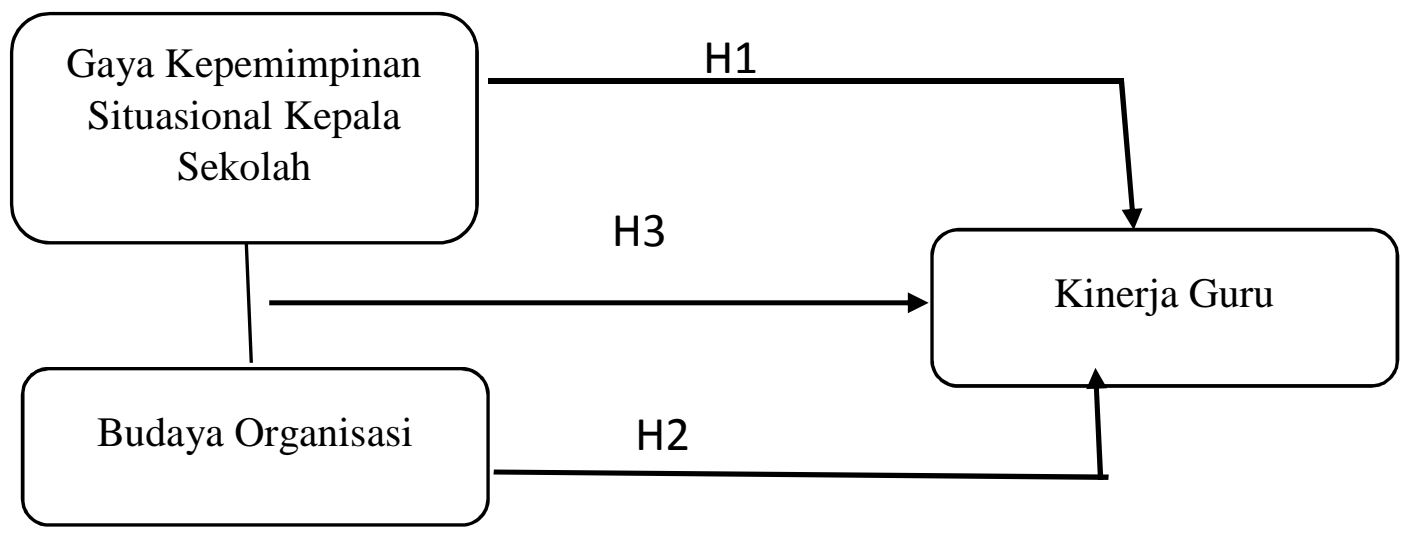

Gambar 1 Theoretical Framework

$\mathrm{H} 1$ = terdapat pengaruh gaya kepemimpinan situasional kepala sekolah terhadap kinerja guru

$\mathrm{H} 2$ = terdapat pengaruh budaya organisasi terhdap kinerja guru

H3 = terdapat pengaruh gaya kepemimpinan situasional kepala sekolah dan budaya organisasi terhadap kinerja guru

\section{METODOLOGI}

Penelitian ini dilakukan dengan menggunakan metode explanatory survey. Metode ini digunakan untuk mengumpulkan informasi faktual melalui angket. Teknik pengumpulan data menggunakan model rating scale yang terentang antara 1 sampai 5 dengan responden penelitian yang berjumlah 38 orang siswa di salah satu SMK swasta di kota Cimahi.

Instrumen pengumpulan data terdiri dari 3 bagian, bagian pertama adalah angket untuk mengukur gaya kepemimpinan situasional kepala sekolah yang terdiri dari dalam 4 indikator yaitu telling, selling, participating, delegating. Bagian kedua adalah angket untuk mengukur budaya organisasi yang terdiri dari 6 indikator yaitu keberaturan cara bertindak, norma-norma, orientasi mutu, keyakinan, aturan yang mengikat dan iklim organisasi. Bagian ke tiga adalah angket untuk mengukur kinerja guru yang terdiri dari 5 indikator yaitu kualitas kerja, ketepatan kerja, inisiatif dalam kerja, kemampuan kerja, dan komunikasi.

Gambaran dari tanggapan responden dalam hal gaya kepemimpinan situasional kepala sekolah, budaya organisasi dan kinerja diperoleh dengan statistik deskriptif menggunakan skor rata-rata tiap bagian. Kemudian teknik analisis untuk menguji hipotesis penelitian menggunakan regresi sederhana dan regresi ganda.

\section{HASIL PENELITIAN DAN PEMBAHASAN}

\section{Gaya Kepemimpinan Situasional Kepala Sekolah}

Deskripsi indicator Gaya kepemimpinan situasional kepala sekolah menurut persepsi responden berada pada kategori Cukup tinggi, sebagaimana ditunjukkan oleh skor rata-rata jawaban responden sebesar 4,04. Tabel 1 menyajikan skor rata-rata dari masing-masing indikator yang dijadikan ukuran gaya kepemimpinan situasional kepala sekolah. 
Tabel 1.

\begin{tabular}{|l|c|c|c|}
\hline \multicolumn{1}{|c|}{ Indikator } & Item & Rata-rata & Penafsiran \\
\hline Telling/mendikte & $1-2$ & 4,17 & Tinggi \\
\hline Selling/menjual & $3-6$ & 4,04 & Tinggi \\
\hline Participating/partisipasi & $7-8$ & 3,94 & Tinggi \\
\hline Delegating/delegasi & $9-12$ & 4,04 & Tinggi \\
\hline & & $\mathbf{4 , 0 4}$ & Tinggi \\
\hline
\end{tabular}

Skor tertinggi berada pada indikator Telling/mendikte. Hal ini mengandung arti bahwa Kepala Sekolah memiliki kemampuan untuk mendikte atau memberi perintah mengenai pelaksanaan tugas dan tanggung jawab kepada guru dengan baik. Sehingga persepsi guru terhadap ketepatan tugas yang diberikan, kepercayaan Kepala Sekolah terhadap guru, intensitas diskusi masalah yang dihadapi, dan efektivitas komunikasi yang dilakukan Kepala Sekolah tergolong tinggi. Adapun indikator yang memiliki bobot skor paling rendah jika dibandingkan dengan lainnya adalah Participating/partisipasi. Hal ini mengandung arri bahwa menurut responden, kepala sekolah memiliki kekurangan dalam hal keterlibatannya ketika melakukan pemecahan masalah, dan keterlibatannya dalam membantu guru.

\section{Budaya Organisasi}

Deskripsi variabel budaya organisasi diperoleh melalui perhitungan frekuensi dan persentase terhadap perolehan data variabel budaya organisasi, sebagaimana tercantum pada lampiran. Berdasarkan perhitungan, diperoleh hasil seperti tampak pada tabel berikut ini:

\section{Tabel 2.}

\begin{tabular}{|l|c|c|c|}
\hline \multicolumn{1}{|c|}{ Indikator } & Item & Rata-rata & Penafsiran \\
\hline Keberaturan Cara Bertindak & $1-4$ & 4,04 & Kuat \\
\hline Norma-norma & $5-8$ & 3,95 & Kuat \\
\hline Orientasi Mutu & $9-10$ & 3,96 & Kuat \\
\hline Keyakinan & 11 & 4,11 & Kuat \\
\hline Aturan yang Mengikat & 12 & 3,76 & Kuat \\
\hline Iklim Organisasi & $13-14$ & 3,97 & Kuat \\
\hline & & $\mathbf{3 , 9 7}$ & Kuat \\
\hline
\end{tabular}

Skor jawaban tertinggi berada pada indikator keyakinan yaitu sebesar 4,11 dan skor rata-rata terendah adalah indikator aturan yang mengikat sebesar 3,76. Pada indikator aturan yang mengikat, fakta yang ditemukan bahwa responden masih acuh pada aturan-aturan yang berlaku di lingkungan sekolah, sehingga menyebabkan kurangnya aturan yang kuat yang berlaku di sekolah. Berbeda dengan indikator aturan yang mengikat, indikator keyakinan yang dilakukan dan dipercayai oleh warga sekolah dipersepsikan tinggi atau kuat salah satunya ditandai dengn hubungan yang baik antara warga sekolah dengan yayasan pusat.

\section{Kinerja Guru}

Deskripsi variabel kinerja guru tetap diperoleh melalui perhitungan frekuensi dan persentase terhadap perolehan data variabel kinerja guru tetap, sebagaimana 
tercantum pada lampiran. Berdasarkan perhitungan, diperoleh hasil seperti tampak pada tabel berikut ini:

Tabel 3

\begin{tabular}{|l|c|c|c|}
\hline \multicolumn{1}{|c|}{ Indikator } & Item & Rata-rata & Penafsiran \\
\hline Kualitas Kerja & $1-3$ & 3,97 & Tinggi \\
\hline Ketepatan/Kecepatan Kerja & $4-6$ & 3,89 & Tinggi \\
\hline Inisiatif dalam Kerja & $7-9$ & 3,87 & Tinggi \\
\hline Kemampuan Kerja & $10-13$ & 3,99 & Tinggi \\
\hline Komunikasi & $14-15$ & 3,79 & Tinggi \\
\hline & & $\mathbf{3 , 9 0}$ & Tinggi \\
\hline
\end{tabular}

Berdasarkan hasil analisis kinerja guru di atas, diketahui bahwa indikator kemampuan kerja memiliki skor tertinggi dibandingkan dengan indikator lainnya yaitu sebesar 3,99. Hal ini mengandung arti bahwa kinerja guru memiliki kinerja yang tinggi dapat dilihat melalui efektivitas kepemimpinan yang guru lakukan di dalam kelas, kemampuan mengelola proses belajar mengajar, pelaksanaan penilaian hasil belajar siswa dan penguasaan landasan pendidikan.

Adapun indikator yang memiliki persentasi paling rendah adalah komunikasi sebesar 3,79. Hal ini mengindikasikan bahwa menurut responden kinerja guru masih memiliki kekurangan dalam hal efektivitas penyampaian materi ajar guru kepada siswa, intensitas kegiatan penelitian guru untuk pendidikan, dan peningkatan kualitas pembelajaran setelah guru melakukan penelitian.

\section{H1: Pengaruh Gaya Kepemimpinan Situasional Kepala Sekolah terhadap Kinerja Guru}

Untuk mengetahui hubungan variabel Gaya Kepemimpinan Situasional Kepala Sekolah terhadap Kinerja Guru dilakukan perhitungan dengan menggunakan uji t dan didapatkan nilai Thitung sebesar 6,123 dan nilai Ttabel (0,05;38-2-1) sebesar 2. Dengan demikian, nilai Thitung > nilai Ttabel $(6,123>2)$, maka H0 ditolak dan H1 diterima. Sehingga dapat disimpulkan bahwa "Ada pengaruh Gaya Kepemimpinan Situasional Kepala Sekolah terhadap Kinerja Guru".

Dan koefisien korelasi antara variabel Gaya Kepemimpinan Situasional Kepala Sekolah terhadap Kinerja Guru yaitu sebesar 0,4558, apabila dihubungkan dengan kriteria interprestasi koefisien korelasi berada pada rentang 0,400 - 0,599 yaitu pada kategori sedang/cukup kuat. Dan koefisien determinasi Gaya Kepemimpinan Situasional Kepala Sekolah terhadap Kinerja Guru yaitu $21 \%$.

Perilaku kepemimpinan atasan sesuai dengan harapan, kepentingan, dan kebutuhan kerja kepala sekolah atau guru, maka hal itu secara langsung atau tidak langsung akan memberikan dukungan terhadap peningkatan kinerja kepala sekolah atau guru. (Djamarah 2010) selain itu, kinerja individu dalam organisasi dipengaruhi oleh banyak faktor, satu diantaranya adalah perilaku kepemimpinan atasan (Djamarah, 2010)

Sehingga dapat disimpulkan bahwa gaya kepemimpinan situasional kepala sekolah merupakan salah satu faktor yang mempengaruhi kinerja guru. Ketika gaya 
kepemimpinan situasional kepala sekolah tinggi maka akan berdampak positif dan signifikan terhadap Kinerja Guru, begitupun sebaliknya.

\section{H2: Pengaruh Budaya Organisasi terhadap Kinerja Guru}

Untuk mengetahui hubungan variabel Budaya Organisasi terhadap Kinerja Guru dilakukan perhitungan dengan menggunakan uji t dan didapatkan nilai Thitung sebesar 2,9172 dan nilai Ttabel $(0,05 ; 38-2-1)$ sebesar 2 . Dengan demikian, nilai Thitung $>$ nilai Ttabel $(2,9172>2)$, maka H0 ditolak dan H1 diterima. Sehingga dapat disimpulkan bahwa "Ada pengaruh Budaya Organisasi terhadap Kinerja Guru".

Dan koefisien korelasi antara variabel Budaya Organisasi dengan Kinerja Guru yaitu sebesar 0,4324, apabila dihubungkan dengan kriteria interprestasi koefisien korelasi berada pada rentang 0,400 - 0,599 yaitu pada kategori sedang/cukup kuat. Dan koefisien determinasi Budaya Organisasi terhadap Kinerja Guru yaitu 19\%.

Sejalan dengan hal ini, beberapa penelitian menyatakan bahwa budaya organisasi berpengaruh terhadap kinerja guru (Karantiano, 2013), serta ada efek positif (Ismiyarto, Suwitri, Warella, \& Sundarso, 2015), (Arifin M., 2015) dan efek signifikansi terhadap kinerja guru (Udin, Luva, \& Hossian, 2013). Ini berarti bahwa peran budaya organisasi sangat penting dalam menentukan keberhasilan guru untuk meningkatkan penampilannya.

Perilaku individu dipengaruhi oleh karakteristik individu dan karakteristik organisasi (Gibson, Luthan, \& Stear, 1996). Kinerja individu merupakan perwujudan perilaku individu. Kinerja individu adalah kinerja organisasi. Menurut Amstrong Budaya organisasi juga merupakan komponen kunci dalam pencapaian misi dan strategi organisasi secara efektif (Sudarmanto, 2009).

Sehingga dapat disimpulkan bahwa Budaya Organisasi merupakan salah satu faktor yang mempengaruhi Kinerja Guru. Ketika Budaya Organisasi kuat maka akan berdampak positif dan signifikan terhadap Kinerja Guru, begitupun sebaliknya.

\section{H3: Pengaruh Gaya Kepemimpinan Situasional Kepala Sekolah dan Budaya Organisasi terhadap Kinerja Guru}

Dari hasil pengolahan data dengan menggunakan perhitungan regresi ganda maka menghasilkan persamaan regresi ganda variabel Gaya Kepemimpinan Situasional Kepala Sekolah dan Budaya Organisasi terhadap Kinerja Guru yaitu $\hat{Y}=$ $8.4653+0.4313 \mathrm{X} 1+0.4983 \mathrm{X} 2$

Selanjutnya, untuk mengetahui tingkat signifikan dari pengaruh penggunaan Gaya Kepemimpinan Situasional Kepala Sekolah dan Budaya Organisasi terhadap Kinerja Guru dilakukan perhitungan dengan munggunakan uji $\mathrm{F}$ maka diperoleh Fhitung sebesar 830,0106 dan nilai Ftabel $(0,05 ; 2 ; 38-2-1)$ sebesar 0,0513 pada taraf signifikansi $5 \%$ dan jumlah responden adalah 38 orang. Dengan demikian, nilai Fhitung $>$ nilai Ftabel $(830,0106>0,0513)$, maka H0 ditolak dan H3 diterima. Sehingga dapat disimpulkan bahwa "Ada pengaruh Gaya Kepemimpinan Situasional Kepala Sekolah dan Budaya Organisasi terhadap Kinerja Guru".

Berdasarkan hasil perhitungan data, diperoleh nilai koefisien korelasi antara variabel Gaya Kepemimpinan Situasional Kepala Sekolah dan Budaya Organisasi terhadap Kinerja Guru yaitu sebesar 0,5475. Apabila dihubungkan dengan nilai interpretasi koefisien korelasi berada pada rentang nilai 0,400 - 0,599 yaitu kategori Cukup. Sehingga dapat disimpulkan terdapat hubungan cukup kuat antara Gaya 
Kepemimpinan Situasional Kepala Sekolah dan Budaya Organisasi terhadap Kinerja Guru

Berdasarkan hasil perhitungan data, diperoleh nilai koefisien determinasi adalah sebesar 30\%. Artinya secara simultan variabel Gaya Kepemimpinan Situasional Kepala Sekolah dan Budaya Organisasi memberikan pengaruh sebesar 30\% terhadap Kinerja Guru. Sisanya sebesar 70\% dipengaruhi oleh faktor lain yang tidak diteliti oleh peneliti.

Sejalan dengan penelitian peneliti, Hubungan antara budaya organisasi dan kepemimpinan dapat dikaitkan dengan kinerja para anggota organisasi. Para peneliti telah meneliti hubungan antara gaya kepemimpinan dan kinerja serta antara budaya organisasi dan kinerja (Ogbonna, 2000). Dengan kata lain, gaya kepemimpinan situasional kepala sekolah dan budaya organisasi mempengaruhi kinerja individu.

\section{KESIMPULAN}

Gaya Kepemimpinan Situasional Kepala sekolah yang meliputi telling/mendikte, selling/menjual, participating/partisipasi, delegating/delegasi. Budaya organisasi yang meliputi keberaturan cara bertindak, norma-norma, orientasi mutu, keyakinan, aturan yang mengikat dan iklim organisasi berada pada katagori tinggi. Kinerja guru meliputi kualitas kerja, ketepatan kerja, inisiatif dalam kerja, kemampuan kerja dan komunikasi berada pada kategori tinggi.

Gaya Kepemimpinan Situasional Kepala sekolah memiliki pengaruh yang signifikan terhadap kinerja guru. Dengan demikian peningkatan gaya kepemimpinan situasional kepala sekolah yang semakin baik akan meningkatkan kinerja guru dalam melakukan tugasnya. Budaya organisasi memiliki pengaruh yang signifikan terhadap kinerja guru. Hal ini menunjukan bahwa tingkat budaya yang kuat merupakan aspek yang berperan dalam peningkatan kinerja guru. Begitupun dengan gaya kepemimpinan situasional kepala sekolah dan budaya organisasi memiliki pengaruh yang positif dan signifikan terhadap kinerja guru. Hal ini, membuktikan gaya kepemimpinan situasional kepala sekolah dan budaya organisasi memiliki pengaruh dalam peningkatan kinerja khususnya guru di sekolah.

Bagi peneliti selanjutnya, diharapkan ada kajian lebih mendalam terhadap kinerja guru dengan faktor-faktor lain yang tidak ada dalam penelitian ini.

\section{DAFTAR PUSTAKA}

Arifin, F. (2014). Organizational Culture, Transformational Leadership, Work Engagement and Teacher's Performance : Test of a Model. International Journal of Education and Research, 2(1), 1-14.

Djamarah, S. B. (2010). Strategi Belajar Mengajar. Jakarta: PT. Rineka Cipta.

Fachrurozi, N (2014). Perbedaan Kinerja Guru Yang Telah Bersertifikasi Dengan Non Sertifikasi Di Kota Surakarta. Surakarta: Universitas Muhammadiyah Surakarta

Gibson, Frederick, J. L., \& Stear. (1996). Organisasi, Perilaku Struktur, Proses. Jakarta: Bianarupa Aksara. Hamzah, U. B., \& Lamatenggo, N. (2012). Teori Kinerja Dan Pengukurannya. Jakarta: PT. Bumi Aksara 
Ismiyarto, Suwitri, S., Warella, Y., \& Sundarso. (2015). Organizational Culture, Motivation, Job Satisfaction and Performance of Employes toward the Implementation of Internal Bureaucracy Reform in the Ministry for the Empowement of State Apparatus and Bureaucracy Reform. Journal of Management and Sustainability, 5(1), 192-199.

Janicijevic, N. (2013). The Mutual impact of Organizational Culture and Struckture. Economic Annals, LVII(198), 35-60.

Karantiano, S. (2013). The Influence of Organizational Culture, Leadership Behavior and Job Satisfaction towards Teacher Job Performance. Indian Journal of Health and Welbeing, 4(9), 1637-1642.

Luthan, F. (2002). Organizational Behavior. New York: Mc.Graw Hill International.

Ogbonna, E. d. (2000). Leadership Style, Organisational Culture and Performance : Empirical Evidence from UK Companies. International Journal of Human Resource Management, 766 - 788.

Robbins, S. P. (2006). Perilaku Organisasi. PT Indeks Kelompok GRAMEDIA.

Sudarmanto. (2009). Kinerja dan Pengembangan Kompetensi SDM Teori, Dimensi Pengukuran, dan Implementasi Dalam Organisasi. Yogyakarta: Pustaka Pelajar.

Sun, S. (2008). Organizational Culture and Its Themes. International Journal of Business and Management, 3(12), 137-141.

Suyadnya, N., Natajaya, N., \& Arya Sunu, G. K. (2013). KORELASI

KEPEMIMPINAN SITUASIONAL KEPALA SEKOLAH, MOTIVASI KERJA

DAN IKLIM KERJA TERHADAP KINERJA GURU PADA GURU SMA

NEGERI 1 TAMPAKSIRING. e-Journal Program Pascasarjana Universitas Pendidikan Ganesha .

Suyanto, \& Djihad, A. (2012). Bagaimana Menjadi Calon Guru dan Guru Profesional. Yogyakarta: Multi Pressindo.

Thoha., M. (2012). Prilaku Organisasi Konsep Dasar dan Implikasinya. Jakarta: PT. Grafindo Persada.

Triwahyuni, L., Abdullah, T., \& Sunaryo, W. (2014). The Effect of Organizational Culture, Transformational Leadership and Self-Confidence to Teachers' Performance. International Journal of Managerial Studies and Research (IJMSR), 2(10), 156-165.

Udin, M. J., Luva, R. H., \& Hossian, S. M. (2013). Impact of Organizational Culture on Employee Performance and Productivity: A Case Study of Telecomunication Sector in Bangladesh. International Journal of Business and Management, 8(2), 63-77. 